\title{
TRP2 mRNA-electroporated Autologous Langerhans-type Dendritic Cell Vaccine
}

National Cancer Institute

\section{Source}

National Cancer Institute. TRP2 MRNA-electroporated Autologous Langerhans-type

Dendritic Cell Vaccine. NCI Thesaurus. Code C99114.

A cancer cell vaccine composed of autologous human Langerhans-type dendritic cells (also known as Langerhans cells or LCs) that are electroporated with mRNA encoding full-length murine tyrosinase-related peptide 2 (TRP2), with potential antineoplastic and immunomodulating activities. Upon vaccination, the TRP2 mRNA-electroporated autologous Langerhans-type dendritic cell vaccine may stimulate the immune system to mount a cytotoxic T-lymphocyte (CTL) response against TRP2-expressing tumor cells. TRP2, a tautomerase involved in the synthesis of melanin, is only expressed in melanomas, melanocytes, and the retina. The LCs are differentiated from CD34 positive hematopoietic progenitor cells. 